\title{
Ratio of total leukocyte count to C-reactive protein: does it help to differentiate infectious fever from engraftment fever in patients undergoing autologous hemato- poietic stem cell transplant?
}

\author{
Sachin Punatar ${ }^{1,2}$, Lingaraj Nayak ${ }^{1,2}$, Avinash Bonda ${ }^{1,2}$, Anant Gokarn ${ }^{1,2}$, Aniket Mohite ${ }^{1}$, Karthik Shanmugam ${ }^{1}$, \\ Deepan Rajamanickam ${ }^{1}$, Alok Gupta ${ }^{1}$, Libin Mathew ${ }^{1}$, Sadhana Kannan ${ }^{3}$, Navin Khattry ${ }^{1,2}$ \\ ${ }^{1}$ HSCT unit, Department of Medical Oncology Tata Memorial Centre, HSCT unit, ACTREC, Kharghar, Navi Mumbai, India \\ ${ }^{2}$ Homi Bhabha National Institute, Anushakti Nagar, Mumbai, India \\ ${ }^{3}$ Department of Biostatistics, Tata Memorial Centre, Paymaster Shodhika, ACTREC, Kharghar, Navi Mumbai, India
}

Dr. Navin Khattry, Professor and BMT Programme

Co-ordinator, HSCT unit, Department of Medical Oncology,

Room 211, Paymaster Shodhika, ACTREC, Kharghar, Navi

Mumbai 410210, Maharashtra, India
Phone +919892501884

E mail: nkhattry@gmail.com

Citation: SPunatar S, Nayak L, Bonda A et al. Ratio of total leukocyte count to C-reactive protein: does it help to differentiate infectious fever from engraftment fever in patients undergoing autologous hematopoietic stem cell transplant? Cell Ther Transplant 2020; 9(2): 40-46.

\section{Summary}

Engraftment fever (EF) is a common complication of autologous HSCT (AHSCT). It is difficult to discern it from infectious fever (IF). We studied the significance of total blood leucocyte count (TLC) to C-reactive protein (CRP) ratio in differentiating EF from IF. 109 consecutive AHSCT patients were retrospectively analysed between March 2011 and August 2013. Breakthrough fever (BF) was defined as new-onset fever preceded by an afebrile period of at least 48 hours. The BF episodes were classified as IF or EF. Infectious fever was diagnosed in case of blood culture positivity, radiological signs of infection, or fever subsiding within 48 hours of changing the antibiotics. Engraftment fever was defined in cases associated with rising leucocyte counts without identifiable infective focus. EF responded well to steroid therapy. Daily TLC and CRP values were obtained from patients' records. Optimal cut-off value of ratio on day of BF was obtained by plotting ROC curve. Sensitivity and specificity were calculated at this value.
Among 109 cases, the breakthrough fever manifested in seventy patients. The median term for BF was day +9 . Sixty-two patients had the EF. Median value of TLC/ $\mathrm{CRP}$ ratio on the day of $\mathrm{BF}$ was significantly higher in patients with EF than with IF (0.139 vs $0.038, \mathrm{p}=0.013)$. With ROC analysis, the AUC value was 0.78 (95\%CI $0.66-0.89, \mathrm{p}<0.0001)$. The ROC curve provided the optimal TLC/CRP value of 0.056 . Using a ratio $>0.056$ for $\mathrm{EF}$, the sensitivity and specificity were $63 \%$ (95\%CI 50 $75 \%)$ and $100 \%(95 \% \mathrm{CI} 63-100 \%)$ respectively. TLC/ CRP ratio $>0.056$ is highly specific for EF. Prospective studies are warranted to confirm these findings.

\section{Keywords}

Total leukocyte count, C-reactive protein, engraftment fever, infectious fever, stem cell transplant, autologous. 


\section{Introduction}

Engraftment-related fever and engraftment syndrome are well-known phenomenon post autologous HSCT. Engraftment syndrome refers to the constellation of features associated with engraftment including fever, skin rash, fluid retention, weight gain, and non-cardiogenic pulmonary edema. These features constitute the major criteria of the proposed definition of engraftment syndrome [1]. However, some studies have defined this syndrome differently and its reported incidence varies widely from $7 \%$ to as high as $59 \%$ in some studies [2-7]. The period of onset of engraftment-related fever often coincides with the time when the patients are likely to have fungal and bacterial infections. Hence, antibiotics are often escalated at the time of onset of breakthrough fever. This leads to increased use of antimicrobials and consequently adds significantly to health care costs.

There is no reliable clinical or laboratory parameter which helps to differentiate engraftment related fever from infectious fever. One study has shown that the ratio of Interleukin-12 to Interleukin-6 could reliably distinguish infectious from non-infectious fever following autologous HSCT [8].
However, measurement of interleukin levels is not available in most transplant centres. Our study stemmed from personal observations that the relative increase in total leukocyte count (TLC) is greater than the relative increase in C-reactive protein (CRP) in patients with engraftment fever whereas the reverse is, generally, seen in infectious fever. With this observation, we aimed to study whether the TLC/CRP ratio helps to distinguish infectious fever from engraftment-related fever in the patients undergoing autologous HSCT.

\section{Patients and methods}

\section{Patient characteristics}

This is a retrospective analysis of all autologous transplants from March 2011 to September 2013 at a single centre. One hundred and nine consecutive autologous transplants were included in the analysis (Table 1). Fifty-three patients had Hodgkin lymphoma, 19 had Non Hodgkin lymphoma, 34 had multiple myeloma and 3 had neuroblastoma. The median age was 32 years (range 2-63 years). Eighty four patients were males. At the time of transplant, 67 (61\%) patients were in complete remission and $37(34 \%)$ were in partial remission.

\section{Table 1. Patient characteristics}

\begin{tabular}{|c|c|c|c|c|c|}
\hline Characteristic & Entire cohort & $\begin{array}{l}\text { Patients with } \\
\text { BF* }\end{array}$ & $\begin{array}{l}\text { Patients with } \\
\text { EF* }\end{array}$ & $\begin{array}{l}\text { Patients with } \\
\text { IF* }^{*}\end{array}$ & $P$ value\# \\
\hline No of patients & 109 & 70 & 62 & 8 & - \\
\hline Median age & 32 (2-63 years) & 34 (8-63 years) & 34 (8-63 years) & 28 (8-55 years) & 0.865 \\
\hline Gender, males (\%) & $84(76 \%)$ & $50(71 \%)$ & $45(73 \%)$ & $5(63 \%)$ & 0.390 \\
\hline $\begin{array}{l}\text { Diagnosis } \\
\text { Hodgkin disease } \\
\text { Non Hodgkin lymphoma } \\
\text { Multiple myeloma } \\
\text { Others }\end{array}$ & $\begin{array}{l}53(49 \%) \\
19(17 \%) \\
34(31 \%) \\
3(3 \%)\end{array}$ & $\begin{array}{l}36(51 \%) \\
14(20 \%) \\
19(28 \%) \\
1(1 \%)\end{array}$ & $\begin{array}{l}32 \\
14 \\
16 \\
0\end{array}$ & $\begin{array}{l}4 \\
0 \\
3 \\
1\end{array}$ & $\begin{array}{l}0.711 \\
0.667 \\
0.561 \\
0.561\end{array}$ \\
\hline $\begin{array}{l}\text { Disease status at transplant } \\
\text { Complete remission } \\
\text { Partial remission } \\
\text { Disease }\end{array}$ & $\begin{array}{l}67(61 \%) \\
37(34 \%) \\
5(5 \%)\end{array}$ & $\begin{array}{l}48(69 \%) \\
19(27 \%) \\
3(4 \%)\end{array}$ & $\begin{array}{l}43 \\
16 \\
3\end{array}$ & $\begin{array}{l}5 \\
3 \\
0\end{array}$ & $\begin{array}{l}0.332 \\
0.337 \\
0.920\end{array}$ \\
\hline Source of stem cells, PBSC (\%) & $103(95 \%)$ & $68(97 \%)$ & 61 & 7 & 0.400 \\
\hline \multicolumn{6}{|l|}{ Conditioning regimens } \\
\hline $\begin{array}{l}\text { Lymphoma* } \\
\text { LACE } \\
\text { LEAM } \\
\text { BEAM }\end{array}$ & $\begin{array}{l}69 \\
1 \\
2\end{array}$ & $\begin{array}{l}47 \\
1 \\
2\end{array}$ & $\begin{array}{l}43 \\
1 \\
2\end{array}$ & $\begin{array}{l}4 \\
0 \\
0\end{array}$ & 0.899 \\
\hline $\begin{array}{l}\text { Multiple myeloma } \\
\text { Melphalan } \\
\text { Melphalan + Bortezomib }\end{array}$ & $\begin{array}{l}31 \\
3\end{array}$ & $\begin{array}{l}17 \\
2\end{array}$ & $\begin{array}{l}14 \\
2\end{array}$ & $\begin{array}{l}3 \\
0\end{array}$ & 0.838 \\
\hline $\begin{array}{l}\text { Neuroblastoma } \\
\text { Busulphan + Melphalan }\end{array}$ & 3 & 1 & 0 & 1 & -- \\
\hline Time to myeloid engraftment & 11 days & 10 days & 10 days & 9 days & 0.703 \\
\hline Time to platelet engraftment & 13 days & 13 days & 13 days & 12 days & 0.802 \\
\hline
\end{tabular}


Chemotherapy and granulocyte colony stimulating factor (G-CSF) were used for stem cell mobilization in 100 (92\%) patients while only G-CSF was used in 4 (4\%) patients. G-CSF with plerixafor was used in 1 patient. Four (4\%) patients did not receive any form of mobilizing drug. All these 4 patients received marrow grafts. All patients with multiple myeloma received melphalan based conditioning regimen, either melphalan alone $(n=31)$ or with bortezomib $(n=3)$. Lymphoma patients received conditioning with lomustine + cytarabine + cyclophosphamide + etoposide [LACE $(n=69)$ ], lomustine + etoposide + cytarabine + melphalan [LEAM $(n=1)]$ or carmustine + etoposide + cytarabine + melphalan [BEAM $(n=2)]$ regimen. Patients with neuroblastoma received busulfan + melphalan conditioning. Peripheral blood stem cells graft was used in 103 (95\%) patients and bone marrow graft was used in $5(5 \%)$ patients. One patient received a combined marrow and PBSC graft. Stem cells were cryopreserved for a median of 43 days (17-301 days). The median dose of CD34 cells infused was $4.6 \times 10^{6}$ per kg. Neutrophil and platelet engraftment occurred at a median of 11 days and 13 days, respectively.

TLC and CRP were measured in the frames of routine blood analyses daily in the morning for all patients from the day of admission to the day of discharge and TLC/CRP ratio was calculated. Complete blood counts were done by Beckman HMX coulter. CRP was measured by the particle-enhanced turbidimetric immunoassay (PETIA) technique. Appropriate clinical and laboratory data were retrieved from patients' files.

\section{Clinical definitions}

Engraftment: Myeloid engraftment was defined as TLC $>1 \times 10^{9} / \mathrm{L}$ for 3 consecutive days or absolute neutrophil count greater than or equal to $0.5 \times 10^{9} / \mathrm{L}$ for 2 consecutive days, whichever was earlier. Platelet engraftment was defined as the first day of consecutive 7 days when platelet count remained about $20 \times 10^{9} / \mathrm{L}$ without need for platelet transfusion.

Peri-engraftment period: Peri-engraftment period was defined as period of 72 hours prior to myeloid engraftment to 96 hours after engraftment.

Breakthrough fever: Fever $>38^{\circ} \mathrm{C}$ with onset in peri-engraftment period (usually during the $2^{\text {nd }}$ week post-transplant) after being afebrile for at least 48 hours. Episodes of breakthrough fever were classified as either infectious fever, or engraftment-related fever.

Continuous fever: Patients with fever persisting over $2^{\text {nd }}$ week post-transplant without an afebrile period, or with afebrile period of $<48$ hours were classified as having continuous fever.

Infectious fever: The condition was classified as infectious fever if blood culture (or culture from any other normally sterile site) was positive, or in case of radiological signs of infection or if fever subsided within 48 hours after change of antibiotics.

Engraftment fever: Engraftment fever was defined as fever with onset in the peri-engraftment period, without any evidence of associated infectious cause, and responding to systemic steroid therapy.

\section{Anti-infective prophylaxis}

All the patients received prophylaxis with an anti-fungal agent (voriconazole or posaconazole) and acyclovir. Antifungal prophylaxis was started on day -1 and continued till resolution of neutropenia. In patients receiving systemic steroids for engraftment fever, antifungal prophylaxis was continued until the steroids were stopped. Acyclovir was given for up to 6 months post HSCT. Patients receiving systemic steroids for engraftment fever also received cotrimoxazole prophylaxis. No antibacterial prophylaxis was performed for the period of neutropenia.

\section{Use of growth factors}

Filgrastim (G-CSF) was used in all autologous transplants. In patients with lymphomas and neuroblastoma, it started on the next day after stem cell infusion $(\mathrm{Day}+1)$. In patients with myeloma, it was started on day +5 post-transplant. In all the patients, it continued until myeloid engraftment.

\section{Treatment strategy for breakthrough fever}

Treatment-related decisions were made at the discretion of treating physician. In general, antibacterial or antifungal drugs were added at the onset of breakthrough fever. The antibiotics were continued if the patient became afebrile by 48 hours. If the patient remained febrile beyond 48 hours and blood culture had grown an organism, then antibiotics were modified according to the sensitivity reports. If the fever persisted beyond 48 hours, and there was no evidence of any infective cause, then systemic steroids were started. In few patients with high clinical suspicion of engraftment fever, systemic steroids were started at the onset of breakthrough fever. Initially methylprednisolone was started at a dose of 1-2 mg per kg per day and subsequently changed to oral prednisolone. Prednisolone was tapered every $3^{\text {rd }}$ to $7^{\text {th }}$ day as per discretion of the attending clinician.

\section{Statistical analysis}

We studied the trends of TLC:CRP ratio during the course of HSCT. We studied the absolute value of this ratio on the day of breakthrough fever to determine if it helps in distinguishing engraftment-related fever from infectious fever. Optimal cut-off value of the ratio on the day of breakthrough was obtained by plotting a receiver operating characteristic (ROC) curve. Sensitivity and specificity indices were calculated from this value. We also calculated the absolute rise of the ratio from its nadir to post-nadir value (i.e the lowest value and the value on the next day) and studied, whether this absolute rise helps to predict the occurrence of engraftment fever. Categorical data were analysed with chi-square test; continuous data with Mann-Whitney test. Analysis was done by SPSS software (version 18).

\section{Results}

Among the 109 patients subjected to autologous HSCT, seventy patients $(64 \%)$ developed breakthrough fever in the $2^{\text {nd }}$ week post-transplant. Fourteen patients (13\%) had continuous fever while $22(20 \%)$ patients did not have fever at any time in the $2^{\text {nd }}$ week. Three patients (3\%) expired prior to day 7 (all 3 due to pneumonia with sepsis). Of the 70 patients 
with breakthrough fever, 19 had multiple myeloma, 36 suffered with Hodgkin lymphoma, 14 had non-Hodgkin lymphoma, and one patient had neuroblastoma. The characteristics and engraftment kinetics of the cohort with breakthrough fever were not different from the entire cohort (Table 1).

The median day of the breakthrough fever onset was day +9 (ranges, day +7 to day+15). Sixty-two patients had engraftment-related fever; 15 of these had a full-blown engraftment syndrome. The overall incidence of engraftment fever was $57 \%$ (62 of 109 patients). Among the 62 patients with engraftment fever, one patient died due to full-blown engraftment syndrome. All others recovered. Peri-engraftment hepatic and renal dysfunction was seen in 2 patients each. Antibiotics were escalated in 35 of 62 (56\%) patients with engraftment fever at the time of onset of breakthrough fever. All the patients with infectious fever got well (Table 2).

\section{Trend of TLC-to-CRP ratio following HSCT in myeloma patients}

The ratio of TLC (expressed in 109/ml) to CRP (expressed in $\mathrm{mg} / \mathrm{dl}$ ) followed a parabolic curve. It had a median value of 12.35 (range 2.34-60) at day -3 of HSCT and gradually declined to a median nadir value of 0.02 (range 0 to 0.16 ) (Fig. 1). The nadir was attained at a median of 9 days post-transplant. A rising trend of the ratio was first evident at a median of 10 days. This was followed by a gradual rise in ratio towards baseline.

\section{Trend of TLC-to-CRP ratio after HSCT in lympho- ma patients}

The curve of TLC:CRP ratio was also parabolic in the patients with lymphoma. The median value of the ratio when starting the conditioning chemotherapy (on day -8) was 5.35 (range 0.41 to 83 ). It reached a nadir median value of 0.01 (range $0-7.55$ ) on day +2 . It remained at the nadir level till day +5 . Rising trend of the radio was first evident on day +6 . A rising trend of the ratio preceded neutrophil engraftment by a median term of 5 days (Fig. 2).

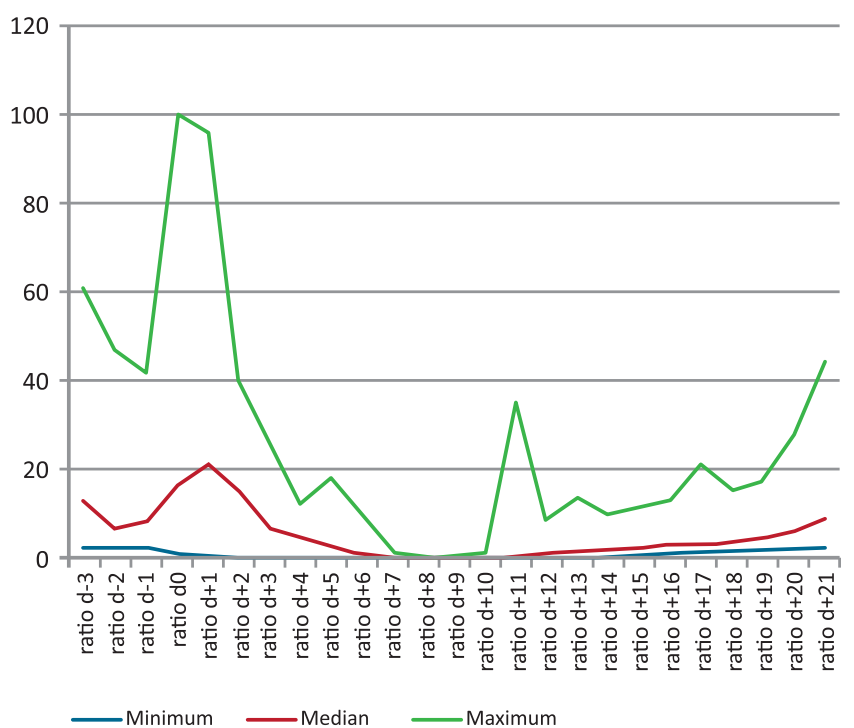

Figure 1. Trend of TLC:CRP ratio during the course of HSCT in myeloma transplants

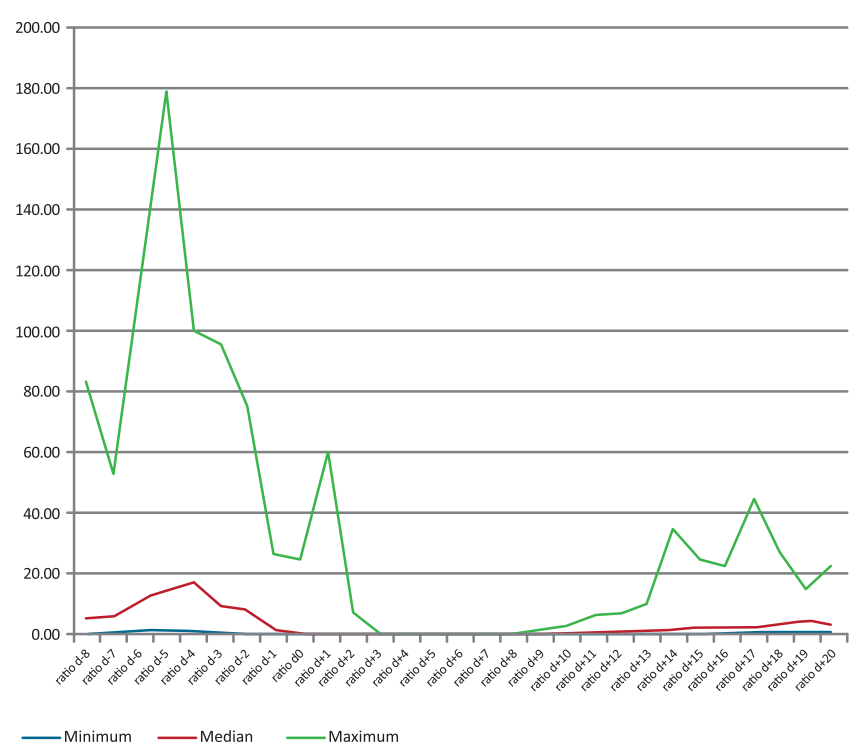

Figure 2. Trend of TLC:CRP ratio during the course of lymphoma transplants

Table 2. Breakthrough fever and clinical outcomes

\begin{tabular}{|l|l|}
\hline Clinical parameter/outcome & No of patients (\%) \\
\hline Patients with breakthrough fever & $70(100 \%)$ \\
\hline Day of onset of breakthrough fever, median (range) & $9(7-15)$ \\
\hline Engraftment fever & $62(89 \%)$ \\
$\quad$ Engrafment syndrome & $81 \%)$ \\
\hline Infectious fever & $811 \%)$ \\
\hline Clinical outcome in engraftment fever (n=62) & $61(98 \%)$ \\
Recovery & $1(2 \%)$ \\
\hline Death & $8(100 \%)$ \\
\hline Clinical outcome in infectious fever (n=8) & $0(0 \%)$ \\
Recovery & \\
Death & \\
\hline
\end{tabular}




\section{Absolute value of the TLC:CRP ratio on the day of breakthrough fever}

We also examined, whether the absolute value of the TL$\mathrm{C}$ :CRP ratio on the day of breakthrough fever may help in identifying the cause of fever. The median value of this ratio in patients with engraftment fever was significantly higher than among the patients with infectious fever (0.139 vs $0.038, \mathrm{p}=0.013$ ). A ROC curve was constructed for TLC:CRP ratio. The area under the ROC curve was 0.78 (95\% CI - 0.66 to $0.89, \mathrm{p}<0.0001$ ). This indicates that the test has potentially good diagnostic usefulness. The curve provided an optimum cut off value of 0.056 to discriminate between engraftment and infective fever (Fig. 3).

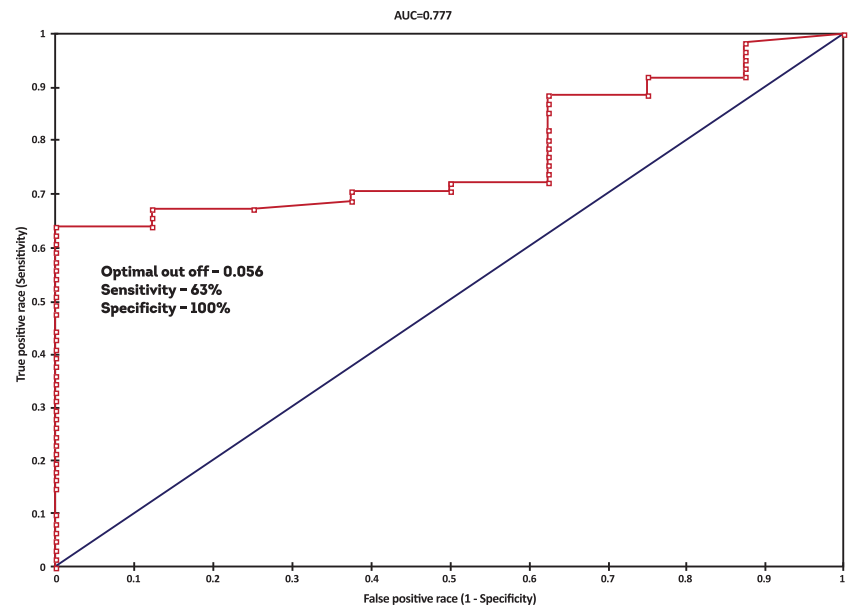

Figure 3. ROC curve for cut-off of absolute value of TLC:CRP ratio on the day of breakthrough fever for detecting engraftment fever

A ratio greater than or equal to 0.056 on the day of breakthrough fever had sensitivity of 63\% (95\% CI $50-75 \%)$ and specificity of $100 \%$ (95\% CI $63-100 \%$ ) for detecting engraftment fever. The positive and negative predictive values of ratio $>0.056$ for engraftment related fever were $100 \%$ (95\% CI $89-100 \%)$ and $26 \%$ (95\% CI - 13-45\%). Thus, a TLC:CRP ratio of $>0.056$ is absolutely specific for engraftment fever.

\section{Absolute rise in ratio from nadir value to pre- dict risk of engraftment fever}

We studied the rise in ratio from its nadir value to the post nadir value (i.e. value on the next day) and attempted to see if a cut-off could be found, thus helping to predict increased risk of developing engraftment related fever. However, at various cut-off values ranging from 0.001 to 0.01 , approximately $60 \%$ of the patients developed engraftment fever. Thus, no particular cut-off value predicting an increased risk of developing engraftment fever could be determined in our patient cohort $(\mathrm{p}=\mathrm{NS}$ ) (Table 3 ). The median increase from the nadir to the post-nadir value was not different in patients with and without engraftment related fever (0.008 vs 0.010 , $\mathrm{p}=0.72$ ).

\section{Discussion}

Engraftment fever is a well-known entity post autologous HSCT and occurs in the peri-engraftment period [1]. How-
Table 3. Incidence of engraftment fever according to absolute rise in ratio from its nadir value to post nadir value

\begin{tabular}{|l|l|}
\hline Cut-off & $\begin{array}{l}\text { Incidence of engraftment } \\
\text { related fever }\end{array}$ \\
\hline 0.001 & $61 \%$ \\
\hline 0.002 & $64 \%$ \\
\hline 0.003 & $63 \%$ \\
\hline 0.004 & $63 \%$ \\
\hline 0.005 & $61 \%$ \\
\hline 0.006 & $60 \%$ \\
\hline 0.007 & $62 \%$ \\
\hline 0.008 & $61 \%$ \\
\hline 0.009 & $60 \%$ \\
\hline 0.010 & $59 \%$ \\
\hline
\end{tabular}

ever, this is also the time when transplant patients may develop fungal and bacterial infections. Unfortunately, there is no laboratory marker or test in routine clinical use which helps to distinguish engraftment related fever versus infectious fever. The distinction is largely based on clinical judgement. Antimicrobials are often escalated in patients who develop breakthrough fever during peri-engraftment period, since it is not always possible to discriminate it from infective fever.

Few studies have tried to differentiate engraftment fever from infectious fever. A study from Memorial Sloan-Kettering Institute suggested that ratio of serum interleukin 12 to interleukin 6 at the time of breakthrough fever helps to discriminate between engraftment and infectious fever [8]. This group studied the levels of various cytokines in serum at various time points following autologous HSCT and found that value of ratio $>4.1$ at the time of breakthrough fever has a sensitivity of $95 \%$ and specificity of $75 \%$ for detecting engraftment fever. Although several functions of interleukin 12 are known, one of the important functions is to enhance the proliferation of hematopoietic progenitor cells [9-11]. Also, it is well established that interleukin- 6 is the major stimulator of C-reactive protein $[12,13]$. Hence, from a biological perspective, the ratio of TLC to CRP could be used as a surrogate marker for the ratio of serum IL-12 to IL- 6 .

A major problem with the use of serum cytokine levels is the lack of availability of these at most centres. On the other hand, measurements of TLC and CRP values are available at most centres and are relatively inexpensive. The cut-off value of TLC/CRP ratio 0.056 identified in our study has a higher specificity, but lower sensitivity than the IL-12 to IL-6 ratio reported in the previous study [8]. In this study, $17 \%$ of episodes of breakthrough fever occurring after neutrophil engraftment were associated with infection. This value is similar to that found in our study (8 of 70 episodes, $11 \%$ ). Similar to our study, the median value of IL-12 to IL-6 ratio was significantly higher in patients with non-infectious fever compared to those with infectious episodes. The study reported a sensitivity and specificity of $95 \%$ and $75 \%$ at a cut- 
off of 4.1. The area under the ROC curve was 0.88 for the IL-12 to IL-6 ratio with 95\% CI being 0.79-0.97.

To conclude, a rising trend of the ratio of TLC:CRP is detected prior to neutrophil engraftment. An absolute value of the ratio greater than or equal to 0.056 at the time of breakthrough fever is highly specific for engraftment fever. Further prospective studies are warranted to confirm the findings of this small study. If the findings are confirmed, they could help to prevent unnecessary use of anti-bacterials and anti-fungals in post-transplant period.

\section{Conflicts of interest}

None declared.

\section{References}

1. Spitzer TR. Engraftment syndrome following hematopoietic stem cell transplantation. Bone Marrow Transplant 2001; 27: 893-898.

2. Lee C, Gingrich RD, Hohl RJ, Ajram KA. Engraftment syndrome in autologous bone marrow and peripheral stem cell transplantation. Bone Marrow Transplant 1995; 16: 175182.

3. Ravoet C, Feremans W, Husson B, Majois F, Kentos A, Lambermont M, Wallef G, Capel P, Beauduin M, Delannoy A. Clinical evidence for an engraftment syndrome associated with early and steep neutrophil recovery after autologous blood stem cell transplantation. Bone Marrow Transplant 1996; 18: 943-947.

4. Edenfield W, Moores LK, Goodwin G, Lee N. An engraftment syndrome in autologous stem cell transplantation related to mononuclear cell dose. Bone Marrow Transplant 2000; 25: 405-409.

5. Cahill R, Spitzer TR, Mazumder A. Marrow engraftment and clinical manifestations of capillary leak syndrome. Bone Marrow Transplant 1996; 18: 177-184.

6. Nurnberger W, Willers R, Burdach S, Gobel U. Risk factors for capillary leakage syndrome after bone marrow transplantation. Ann Hematol 1997; 74: 221-224.

7. Moreb JS, Kubilis PS, Mullins DL, Myers L, Youngblood $\mathrm{M}$, Hutcheson C. Increased frequency of autoaggression syndrome associated with autologous stem cell transplantation in breast cancer patients. Bone Marrow Transplant 1997; 19: 101-106.

8. Tuma R, Almyroudis N, Sohn S, Panageas K, Rice R, Galinkin D, Blain M, Montefusco M, Pamer E, Nimer Sd, Kewalramani T. The serum IL-12:IL-6 ratio reliably distinguishes infectious from non-infectious causes of fever during autologous stem cell transplantation. Cytotherapy. 2006; 8: $327-334$

9. Trinchieri G. Interleukin-12: a cytokine produced by antigen-presenting cells with immunoregulatory functions in the generation of T-helper cells type 1 and cytotoxic lymphocytes. Blood 1994; 84: 4008-4027.
10. Trinchieri G. Interleukin-12 and the regulation of innate resistance and adaptive immunity. Nat Rev Immunol. 2003; 3: 133-146.

11. Wolf SF, Sieburth D, Sypek J. Interleukin 12: a key modulator of immune function. Stem Cells 194; 12: 154-168.

12. Jones SA, Novick D, Horiuchi S, Yamamoto N, Szalai AJ, Fuller GM. C-reactive protein: a physiological activator of interleukin 6 receptor shedding. J Exp Med. 1999; 189: 599604.

13. Pepys MB, Hirschfield GM. C-reactive protein: a critical update. J Clin Invest. 2003; 111: 1805-1812. 


\title{
Соотношение количества лейкоцитов и С-реактив- ного белка в крови: поможет ли это дифференци- ации между инфекционной лихорадкой и синдро- мом приживления у пациентов после аутологичной трансплантации гемопоэтических стволовых клеток?
}

\author{
Сачин Пунатар ${ }^{1,2}$, Лингарадж Наяк ${ }^{1,2}$, Авинаш Бонда ${ }^{1,2}$, Анант Гокарн ${ }^{1,2}$, Аникет Мохите ${ }^{1}$, Картик Шанмугам ${ }^{1}$, \\ Дипан Раджаманикам ${ }^{1}$, Алок Гупта ${ }^{1}$, Либин Мэтью ${ }^{1}$, Садхана Каннан ${ }^{3}$, Навин Хаттри ${ }^{1,2}$ \\ ${ }^{1}$ Отделение ТКМ, Департамент медицинский онкологии, АCTREC, Харгар, Нави Мумбай, Индия \\ ${ }^{2}$ Национальный институт Хоми Бхабха, Анушакти Нагар, Мумбаи, Индия \\ 3 Департамент биостатистики, Мемориальный центр Тата, Пэймастер Шодика, ACTREC, Харгарб Нави Мумбай, Индия
}

\section{Резюме}

«Лихорадка приживления» (ЛП) является частым осложнением аутологичной трансплантации гемопоэтических стволовых клеток (ТГСК). Ее сложно отличить от инфекционной лихорадки (ИЛ). Мы исследовали значимость показателя соотношения общего числа лейкоцитов крови к концентрации С-реактивного белка при дифференциальном диагнозе между ЛП и ИЛ. Группа из 109 пациентов после ауто-ТГСК была обследована ретроспективно в период между мартом 2011 г. и августом 2013 г. Лихорадочное состояние (ЛС) определялось как лихорадка, развивающаяся de novo после афебрильного периода более 48 часов. Эпизоды ЛС классифицировали как ЛП или ИЛ. Инфекционную лихорадку диагностировали в случае позитивной гемокультуры, радиологических симптомов инфекции или лихорадки, продолжающейся в течение 48 часов после смены антибиотика. «Лихорадку приживления» определяли в случаях, связанных с повышением лейкоцитоза без очевидного инфекционного очага. ЛП хорошо отвечала на лечение стероидными гормонами. Ежедневные показатели лейкоцитоза и С-реактивного белка фиксировали по историям болезни. Оптимальный показатель отсечения (cutoff value) данного соотношения на день появления лихорадочного состояния определяли методом построения кривых ROC. Чувствительность и специфичность метода вычисляли по этому показателю.
По результатам анализа 109 случаев, лихорадочные состояния проявились у 70 пациентов. Медианным сроком развития лихорадочного состояния был день +9 после ТГСК. 62 пациента имели ЛП. Медиана соотношения лейкоцитоза к С-реактивному белку в день развития лихорадочного состояния была значительна повышена у пациентов с ЛП по сравнению с ИЛ (соответственно, 0,139 и 0,038, $\mathrm{p}=0,013$ ). При ROC-анализе, площадь под кривой (AUC) была 0,78 (95\%CI - 0,66-0,89, p<0,0001). Из графика ROC вычислено оптимальное соотношение лейкоцитоза к С-реактивному белку, равное >0.056 для «лихорадки приживления» при чувствительности и специфичности, соответственно, 63\% (95\% СI 50-75\%) и 100\% (95\%СI 63-100\%). Соотношение числа лейкоцитов к С-реактивному белку $(>0,056)$ высоко специфично для лихорадки приживления. Необходимы проспективные исследования для подтверждения этих результатов.

\section{Ключевые слова}

Лейкоцитоз общий, С-реактивный белок, лихорадка приживления, инфекционная лихорадка, трансплантация стволовых кроветворных клеток, аутологичная. 